Journal of Engineering and Science Research 3(1):18-23,2019

e-ISSN:2289-7127

CRMPPublications, 2019

DOI:10.26666/rmp.jesr.2019.2.1

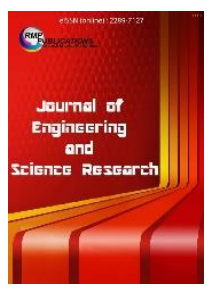

\title{
The Effect of Desulfovibrio Desulfuricans to Carbon Steel Grade API 5L X70
}

\author{
Nur Bazilah binti Ishak ${ }^{1}$, Zamzilawati binti Abdullah 2, Norrizah binti Abd Wahab ${ }^{3}$ \\ ${ }_{1,3}$ Politeknik Sultan Haji Ahmad Shah, \\ ${ }^{2}$ Politeknik Mukah
}

\begin{abstract}
Microbiologically Influenced Corrosion (MIC) caused by the presence of Sulfate-reducing bacteria (SRB) is a big concern in heavy industries. Pipeline infrastructure may experience severe metal loss due to corrosion induced by the species and can potentially lead to catastrophic failure. By studying SRB growth condition, important parameter can be controlled to prevent or slow down a corrosion process. This study discussed on the effect of $\mathrm{pH}$ value to the corrosion growth rate on API 5L X70 low carbon steel subjected to outer part of underground pipeline. In this research, the type of SRB that's been used is Postgate C of Desulfovibrio Desulfuricans. There are 80 numbers of samples prepared with various $\mathrm{pH}$ value and temperature, which each of the samples contains two coupon steel immersed in the medium together with SRB for 7, 14, 21 and 28 days. The process in determining weight loss is analyzed and the corrosion rate for each steel sample is identified by weight loss. The result is plotted and analyzed, the particular $\mathrm{pH}$ values and temperature affect the growth of SRB in the medium where the existence of SRB could accelerate the corrosion rate towards the steel surface of API X-70. The samples are exposed to SRB in days' time. This experiment aims to determine the optimum temperature for SRB growth and demonstrate the corrosion rate simulation using One-Factor-at-A-Time method (OFAT) method. The consequences of SRB activity, it is shown that pitting corrosion produced on the surface of steel. In fact, the sulphur element is identified as one of the corrosion products due to SRB activity.
\end{abstract}

Key words: Desulfovibrio Desulfuricans; corrosion; SRB growth; effect of $\mathrm{pH}$

\section{Introduction}

SRB is the main bacteria that cause corrosion in pipelines. Therefore, based on previous studies, several parameters need to be investigated to obtain the optimum value for controlling the rate of bacterial growth. This study also produces a pipeline corrosion which changes of any parameters can predict the rate of bacterial growth in more accurate and faster manner.

This study shows the systematic assessment procedure for evaluation of the current and future pipeline corrosion condition that can be developed based on the in-line inspection data. The proposed reliability-based procedure will offer a variety of approaches from data statistical analysis, correction method for the errors of the corroded inspection data and prediction of pipeline integrity.

The findings from this research able to reduce the uncertainties associated with corrosion data, environmental loading and material properties. This hopefully, assists operation management in decision- making during future inspection, repair, maintenance and rehabilitation. Moreover, it will improve the accuracy of pipeline assessment in order to secure the pipeline reliability within a designed service period.

The most common cell morphologies of sulfatereducing bacteria (SRB) are curved (vibrio-type) and oval to rod-shaped (bacillus-type); their diameters usually range from 0.5 to $2 \mu \mathrm{m}$. Many SRB are actively motile by flagella. Other forms are spheres and long multi-cellular filaments. Several types of SRB tend to grow in clumps or cell aggregates and stick to surface. Nutritionally, SRB may be divided into two major groups. Species of the first group carry out an incomplete oxidation of organic substrates with acetate as an end product. Species of the second group oxidize organic substrate, including acetate, completely to CO2. Most incompletely oxidizing SRB may grow rather fast under optimum conditions and reach doubling times of about 10 hours. The beststudied representatives are Desulfovibrio species that can be easily isolated from nearly every environment [1]. For most, lactate is an excellent substrate that is

*Corresponding Author: Nur Bazilah binti Ishak, Politeknik Sultan Haji Ahmad Shah, email:


Nur Bazilah Ishak, Zamzilawati Abdullah \& Norizah Abd Wahab/Journal of Engineering and Science Research, 3(1) 2019, Pages:18-23

oxidized to acetate and $\mathrm{CO} 2$.

this study. Chemical composition for the coupon shall be determined by using X-ray dispersive spectra

2. Literature Review

2.1 Material and Experimental

Carbon steel pipe grade API 5L-X70 was used in
(EDS) and analyse the data with the standard chemical composition for steel grade API X-70 as shown in Table 2.1.

Table 2.1: Chemical Composition for Steel API X70

\begin{tabular}{|c|c|c|c|c|c|c|c|c|c|c|c|c|}
\hline $\mathbf{C}$ & $\mathbf{M n}$ & $\mathbf{S i}$ & $\mathbf{P}$ & $\mathbf{S}$ & $\mathbf{C r}$ & $\mathbf{N i}$ & $\mathbf{M o}$ & $\mathbf{V}$ & $\mathbf{T i}$ & $\mathbf{N b}$ & $\mathbf{C u}$ & $\mathbf{F e}$ \\
\hline 0.06 & 1.05 & 0.27 & 0.006 & 0.002 & 0.02 & 0.20 & 0.008 & 0.05 & 0.02 & 0.05 & 0.24 & $\mathrm{Bal}$ \\
\hline
\end{tabular}

The sample was cut from the original API5L-X70 taken from Petroleum Nasional Berhad (PETRONAS) site form Sungai Ular, Kuantan yard in oil and gas pipe to a $10 \mathrm{~mm}$ x $20 \mathrm{~mm}$ size with total 80 coupons provided to complete all the experiments. All coupons will put in anaerobic bottle 2 pieces per bottle. Every sample has to prepared followed by several processes. There are several steps before the experimental starts:
a) Cutting process
b) Grinding process
c) Polishing and cleaning process with Sic paper
d) Coating process
e) Weighing and measuring
f) Labelling and stored

\subsection{Test Parameter}

$\mathrm{pH}$ conditions are the ambient test parameters studied in this work. The parameters vary to investigate an optimal value for the bacterial growth. There are five $\mathrm{pH}$ values to be tested, which are 5.5, 6.5, 7.5, 8.5 and 9.5. Then, the selected $\mathrm{pH}$ value is based on the judgment were in theory the corrosion occurs more rapidly in an acidic condition. [2] SRB can grow in conditions within a $\mathrm{pH}$ range from 5.0 to 10.0 and temperatures from $5^{\circ} \mathrm{C}$ to $50^{\circ} \mathrm{C}$. Moreover, the value of $\mathrm{pH}$ and temperature used as a parameter to change as different geographical $\mathrm{pH}$ values and different temperatures. Brenda and Jason, (2007), SRB can grow within $\mathrm{pH} 4$ to 8 and temperature 50 to $105^{0} \mathrm{~F}\left(5^{\circ} \mathrm{C}\right.$ to $\left.50^{\circ} \mathrm{C}\right)$

The length of duration is also the tested, which gives a significant effect on the test data. Most bacteria will corrode most rapidly in the early stages of coupon exposure to the atmosphere. The test duration will be conducted in 7, 14, 21 and 28 days.

\section{RESULTS AND DISCUSSION}

The first experiments are the coupon of steel API $\mathrm{X}-70$ which has been cleaned and cut to the size into $10 \mathrm{~mm} \times 20 \mathrm{~mm}$ and the coupon is put in the anaerobic bottle together with the medium of SRB (Postgate C) to assess the growth of corrosion in coupon. An experiment conducted for 28 days, and will be observed every 7 days to see the bacteria growth in the anaerobic bottle exists. To measure the weight loss due to Postgate $\mathrm{C}$ micro activity, the experiments are done in 2 batches with different parameters. Two numbers of coupons are used for each tested parameter.

Table 3.1 shows the tested parameter. The $1^{\text {st }}$ batch experiment the medium $\mathrm{pH}$ is constant at $\mathrm{pH} 7.5$ and varies in temperature and exposure time. The $2^{\text {nd }}$ batch experiment, the optimum temperature from $1^{\text {st }}$ batch results shall be taken as constant parameter and varies in medium $\mathrm{pH}$ and exposure time.

Table 3.1: Test Parameter

\begin{tabular}{|c|c|c|c|}
\hline $\begin{array}{c}\text { Batch } \\
\text { Experiment }\end{array}$ & $\begin{array}{c}\text { Constant } \\
\text { Parameter }\end{array}$ & Exposure Time (Day) & Variable Parameter \\
\hline 2 & Temperature & $7,14,21$ and 28 & $\mathrm{pH}: 5.5,6.5,7.5,8.5$ and 9.5 \\
\hline
\end{tabular}




\subsection{SRB Corrosion Studies on pH}

The study of SRB influenced corrosion by the effect of $\mathrm{pH}$ was tested in anaerobic bottle within 28 days. For this experiment, corrosion rate in $\mathrm{mm} /$ year was calculated from initial weight minus by final weight. This weight loss is due to corrosion pits on the surface of a steel sample is distributed unevenly. Therefore, the presence of SRB can cause corrosion pits on the sample.

The 1st batch experiment, the experiment temperature is constant and varies in $\mathrm{pH}$ and exposure time. This experiment aims to determine the optimum $\mathrm{pH}$ for SRB growth and demonstrate the corrosion rate simulation using One-Factor-at-A-Time method (OFAT) method.

Environmental factors are evaluated to study the characteristics of SRB growth, which are temperature and $\mathrm{pH}$. The exposure time also characteristics of SRB growth. In the experiment, the temperature of medium is maintained at $37^{\circ} \mathrm{C}$. Table 3.2 shows the corrosion rate $(\mathrm{mm} / \mathrm{yr})$.

Table 3.2: Corrosion Rate of Sample with Different $\mathrm{pH}$

\begin{tabular}{|c|l|l|l|c|c|}
\hline \multirow{2}{*}{$\begin{array}{c}\text { Incubation time } \\
\text { (day) }\end{array}$} & \multicolumn{4}{|c|}{$\mathrm{pH}$} & \\
\cline { 2 - 6 } & 5.5 & 6.5 & 7.5 & 8.5 & 9.5 \\
\hline 7 & 0.04358 & 0.02702 & 0.0373 & 0.03935 & 0.0346 \\
\hline 14 & 0.01354 & 0.03941 & 0.0346 & 0.02644 & 0.02673 \\
\hline 21 & 0.0622 & 0.04922 & 0.04102 & 0.02201 & 0.02255 \\
\hline 28 & 0.0735 & 0.05844 & 0.06173 & 0.04031 & 0.05417 \\
\hline
\end{tabular}

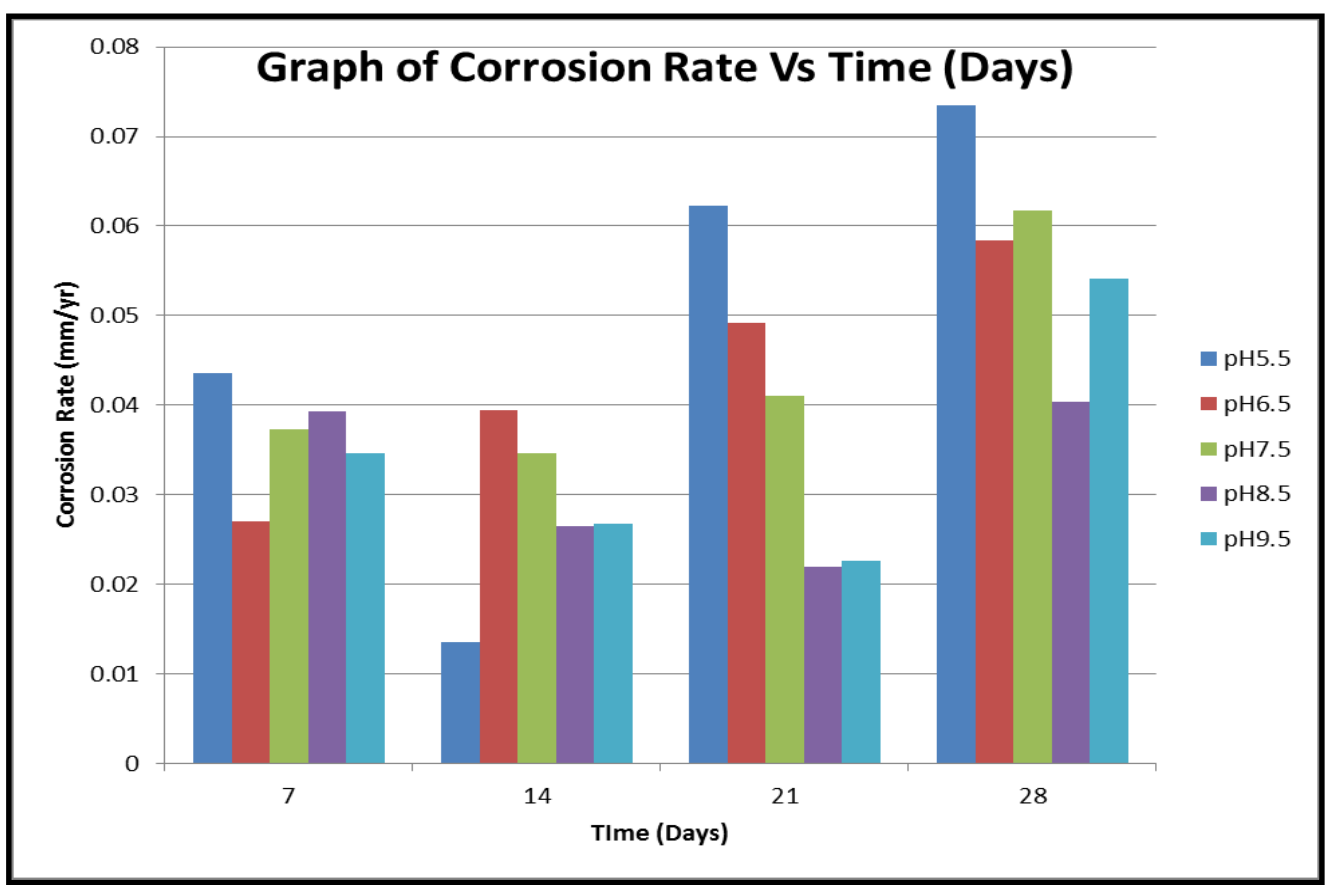

Figure 1.0: Corrosion Rate at Different $\mathrm{pH}$

From Table 3.2 and Figure 1.0 show the result of the experiment. In this experiment, at $\mathrm{pH} 5.5$ the corrosion rate is high. The experiment shows that the bacteria growth well in an acidic medium. The experiment also shows that the corrosion rate is increasing when the incubation time is increased. From the graph, the optimum corrosion rate is at $\mathrm{pH} 5.5$ and incubation time of 28 days. From the data gathered, the corrosion rate is decreasing when the medium $\mathrm{pH}$ more alkaline.

The concluding result can be obtained from the table Table 3.3 and Figure 2.0 below. This chart is to show the effect of bacteria growth. From the chart, the exposure time of 28 days gives the maximum corrosion rate at pH5.5. From Table 3.3 and Figure 2.0 shows the result of the experiment. In this experiment, at $\mathrm{pH} 5.5$ the corrosion rate of sample is high. The experiment 
Nur Bazilah binti Ishak, Zamzilawati binti Abdullah \& Norizah binti Abd Wahab/Journal of Engineering and Science Research,3(1) 2019, Pages:18-23

shows that the bacteria growth well in an acidic medium. Based from [3], the corrosion rate depends on the oxygen dissolved between $\mathrm{pH} 4$ to 10 and the lower the $\mathrm{pH}$, the higher the rate of corrosion [4]. From previous studies reveals that SRB can grow in conditions within the $\mathrm{pH}$ range 5.0 to 10.0 and temperatures $5^{\circ} \mathrm{C}$ to $50^{\circ} \mathrm{C}$ [2]. So that, the experiment shows that SRB present for every $\mathrm{pH}$, but for Postgate $\mathrm{C}$ medium the SRB growth well at $\mathrm{pH} 5.5$.

Table 3.3: Corrosion Rate due to Different $\mathrm{pH}$ in 28 days Incubation Time

\begin{tabular}{|c|c|c|c|}
\hline $\mathrm{pH}$ & $\begin{array}{c}\text { Average weight loss/area } \\
\left(\mathrm{g} / \mathrm{cm}^{2}\right)\end{array}$ & $\begin{array}{c}\text { Time } \\
\text { (hour) }\end{array}$ & $\begin{array}{c}\text { Corrosion Rate } \\
(\mathrm{mm} / \text { year })\end{array}$ \\
\hline $\mathrm{pH} 6.5$ & 0.00352 & 672 & 0.0584 \\
Control & 0.00042 & 672 & 0.0069 \\
\hline $\mathrm{pH} 7.5$ & 0.00372 & 672 & 0.0617 \\
Control & 0.00513 & 672 & 0.0085 \\
\hline $\mathrm{pH} 8.5$ & 0.00243 & 672 & 0.0403 \\
Control & 0.00081 & 672 & 0.0134 \\
\hline $\mathrm{pH} 9.5$ & 0.00327 & 672 & 0.0542 \\
\hline Control & 0.00103 & 672 & 0.0171 \\
\hline
\end{tabular}

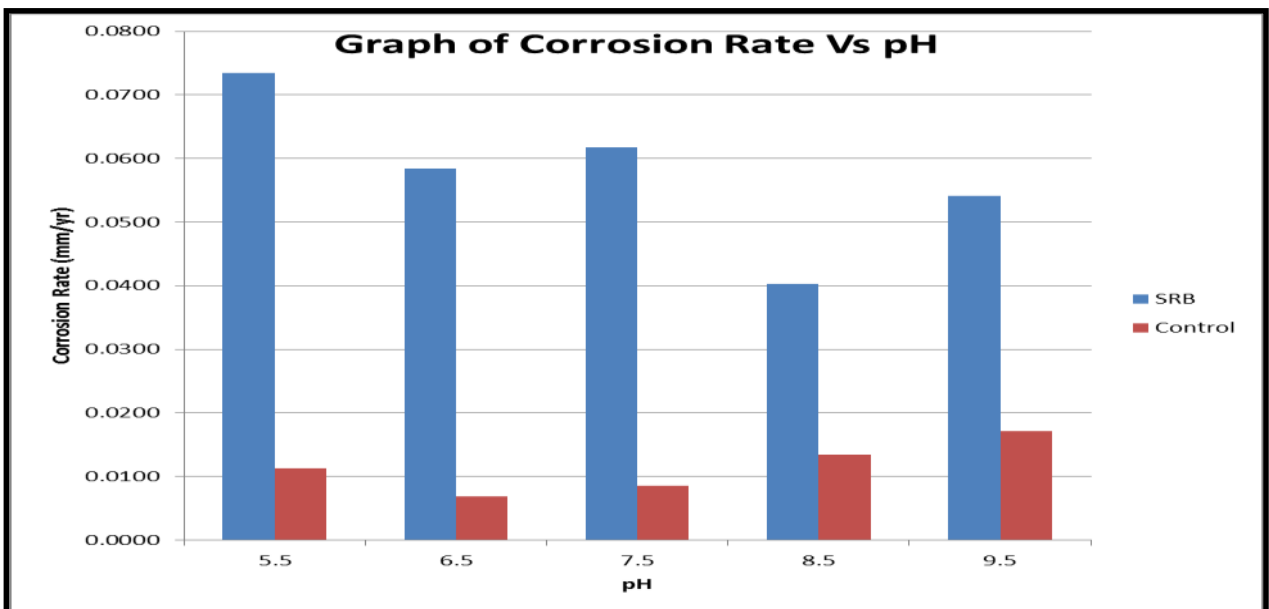

Figure 2.0: Graph of Corrosion Rate by SRB Influenced Different $\mathrm{pH}$

\section{Conclusion}

The concluding result for the optimum corrosion rate for these three parameter can be obtain in Table 4.1 and Figure 3.0.

Table 4.1: Optimal Corrosion Rate for $\mathrm{pH} 5.5$ at Temperature $37^{\circ} \mathrm{C}$

\begin{tabular}{ccc}
\hline Time (days) & pH5.5 & Control \\
\hline 7 & 0.0436 & 0.0033 \\
14 & 0.0135 & 0.0040 \\
21 & 0.0622 & 0.0113 \\
28 & 0.0735 & 0.0113 \\
\hline
\end{tabular}


From Table 4.1, the maximum corrosion rate for temperature $37^{\circ} \mathrm{C}$ is $0.0735 \mathrm{~mm} / \mathrm{yr}$ when $\mathrm{pH} 5.5$ and incubation time is 28 days (672 hour). From the result, it is shown that the corrosion rate is higher at these three parameters which are $\mathrm{pH} 5.5$, temperature $37^{\circ} \mathrm{C}$ and incubation time 28 days

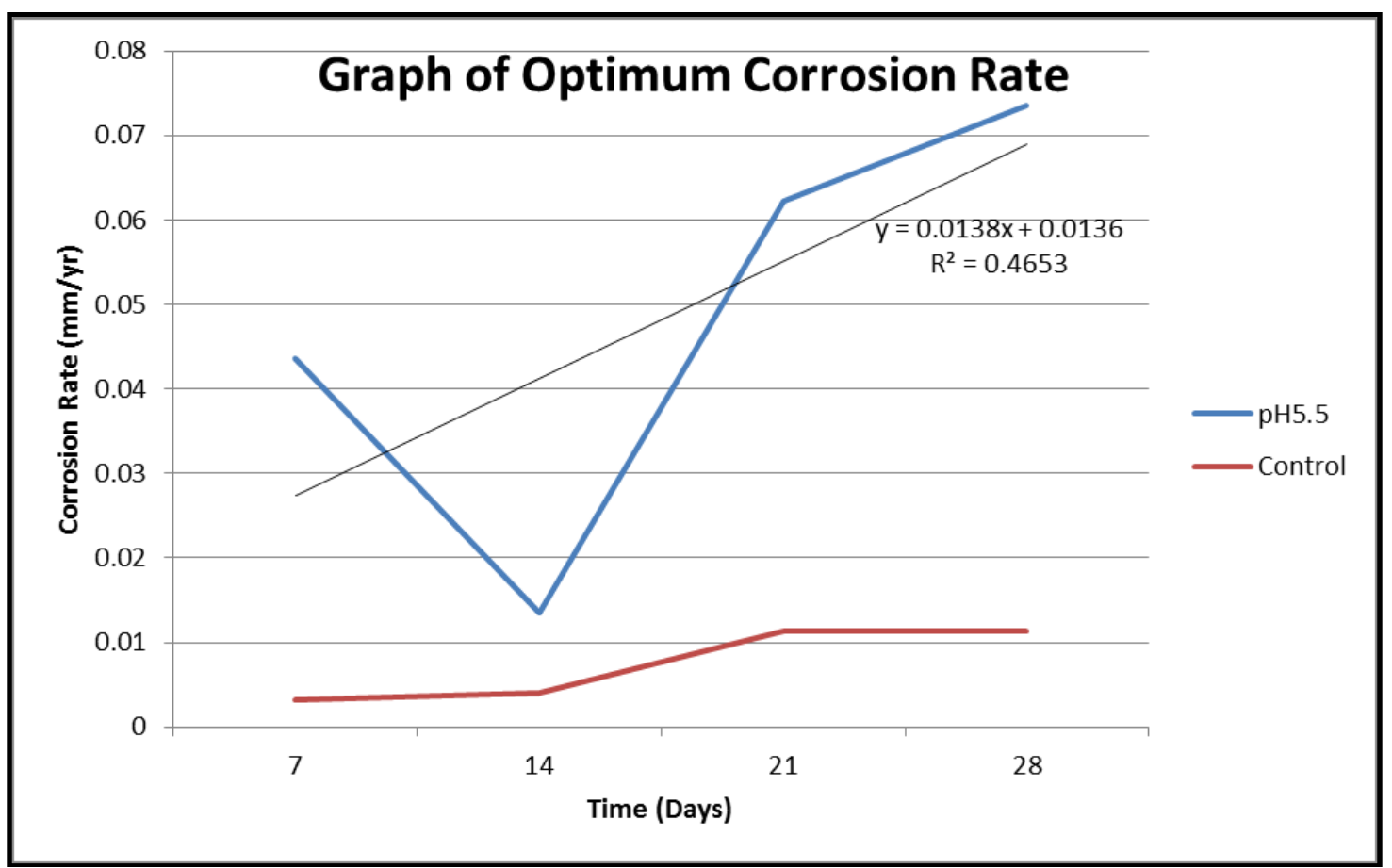

Figure 3.0: Corrosion rate against exposure time for $\mathrm{pH} 5.5$ and Temperature $37^{\circ} \mathrm{C}$

Figure 3.0 illustrates the corrosion rate, $\mathrm{Cr}$ against exposure time. The result indicated that Corrosion rate can be divided into two stages. The corrosion rate should be proportional to exposure time but at day 14 , the $\mathrm{Cr}$ is dropping. This is maybe some of the bacteria are death and this will decrease the corrosion process. The change of the environment for example the $\mathrm{pH}$, temperature and the nutrient supply to bacteria might be the reason that effecting the growth of the bacteria. At 14 to 21 days, the Corrosion rate reaches the $2^{\text {nd }}$ stage where the corrosion rate increased quickly during this stage.

The correlation between SRB for Postgate C medium with $\mathrm{pH} 5.5$ and temperature $37^{\circ} \mathrm{C}$ shows the coefficient of correlation, $\mathrm{R}^{2}$ is 0.47 which is the value indicated medium good correlation. Based on [5] she defines the correlation as table 4.2.

Table 4.2: Correlation Indicated Based from Animator (1996)

\begin{tabular}{cc}
\hline $\mathbf{R}^{2}$ & Correlation Types \\
\hline$<0.25$ & Poor \\
$0.26-0.55$ & Medium good \\
$0.56-0.80$ & Good \\
$>0.80$ & Very Good \\
\hline
\end{tabular}



Research,3(1) 2019, Pages:18-23

As a conclusion, $\mathrm{pH}$ also the crucial factors affecting the growth of SRB beside temperature. Finding in this experiment:

i) The optimum $\mathrm{SRB}$ growth is at $\mathrm{pH} 5.5$ and the exposure time of 28 days while the temperature is $37^{\circ} \mathrm{C}$

ii) From all $\mathrm{pH}$ condition, the bacteria growths very fast from day 1 until day 7 accept at $\mathrm{pH}$ 5.5. After day 7, the bacteria growth is decreasing.

iii) The bacteria growth very well in acidic condition which is at range $\mathrm{pH} 5.5$ to $\mathrm{pH} 6.5$.
References:

[1] Postgate J. R. (1984). The sulphate reducing bacteria, $2^{\text {nd }}$ ed. England: Cambridge Universiti Press.

[2] Javaherdashti R., (1999), A review of some characteristics of MIC caused by SulphateReducing Bacteria: past present and future, Anticorrosion Methods and Materials, 46, pp.173180.

[3] Winston R., Uhlig H. (2008), Corrosion and corrosion control, A John Wiley \& Sons, Inc., Publication.

[4] Dexter, S.C., Moettus, L.N., Lucas K.E., (2003). On Mechanism of Cathodic Protection. Materials Performance 41(10). 598-607.

[5] Agostini R.A and Young R.D, (1996). A case history investigation of microbiologically influenced corrosion in a west Texas water flood. microbilogically induced corrosion of Oil and Gas Production system, NACE International Publications, pp. 122-127. 